for sme days at first, when I made very special inquiries, I foun't that no rain had fallen within roo miles of Madiras. It may perhaps be worth mentioning that from the 8 th to the 14 th we have had the strange phenomenon of a bright green sun at sunrise and sunset, the sun appearing as a rayle-s globe, at which you could easily look, and yet so sharply defined that sunspots could be well seen with the nalsed eye. On the aznd again, two days after the electricity had gone to positive, the green sun reappeared, and has now changed to a sort of golden green. I do not say that there is any connection betifeen the two, but they seem worth mentioning together. I have got a large number of observations which I will reduce as soon as possible, and send to the Royal Society of Edinburgh, but there is no use doing this till things return to their normal state. It is worth pointing out that observations made at intervals of six hour: might have entirely failed to find the negalive electricity. usually, for convenience, take observations at 9 a.m., befure leaving for cullege, and the next would be at three, and both these are always positive. I have not got the exact scale of my electrometer, but I find that Ioo Daniell's cells give only 24 div. of a deflection. I am very much disappointed that I have not got my new instrument yet. Had I had it I would have been able to get simultaneous observations carried on at Madras and at a place forty miles to the west, which might have given valuable results. My present instrument, 1 hough working better than before, needs constant recharging. For example, at noon yesterday the earth reading was 1750 , and at six this morning it was only I 440 .

Christian College, Madras, September 26

\section{Unusual Cloud-Glow after Sunset}

YESTERDAY evening a most extraordinary sunset effect was seen here, which made a deep impression on all who observed it. The sky was nearly clear when the sun set at 4.18 , and the air transparent. A few cirrccumulus fleeces became lighted up with a pink and then with a deep red colour immediately after sunset. A very peculiar greeni- $h$ and white opalescent haze now appeared about the point of the sun's depariure, and shone as if with a light of its own, near the horizon. The upper part of this pearly mist soun assumed a pink colour, while the lower part was white, green, and greenish-yellow. About 4.35 the sky from near the horizon towards the zenith had begun to turn to a brilliant but delicate pink, and some pink cirrus-like streaks stretched apparently hurizontally towards the south-eat. The coloured portion of the sky spread out like a sheaf from the horizon, and apparently consisted of a very high, thin filmy cirrus disposed in transverse bands or ripples, close together, and very delicate in form, outline, and tint. Below the pink, and between it and the point where the sun had set, remained the very curious, opalescent, shining, green and white vapour, hanging, as it were, vertically, and changing very little during many minutes. The borders of the pink sheaf were definite, and finely contrasted with the deep blue sky. As darkness came on, the pink glow seemed to increase in brightness, and at five o'clock cast a fine weird light over the hills. The moon was now bright in the soutb-east, and began to cast dark shadows. About five the crlour slowly receded from the part nearest the zenith towards the horizon, and as it retired left a clearly visible filmy ripple of cirrus of a faint gray tint. At 5.25 the greater part of the coliur was gone, and the cloud remained bright only near the horizon. At 5.32, however, it began to grow again, and in a short time (5.40) the whole extent of the film was again glowing bright pink, producing a most striking effect in contrast with the silvery moon, dark sky, and bright stars in the north and east. The pink light then slowly withdrew towards the horizon, remaining bright and deep coloured low down till 5.50. At 5.58 the last pink disappeared. The whole phenomenon from first to last was in the highest degree peculiar and striling. It was remarkable, first, for the interval which elapsed between the time of sunset and the time at which the cloud became bright, next for the light, filmy character of the cloud, thirdly for the bright green glow near the place of sunset, fourthly for the small transverse ripple form of the cloud, fifthly for the permanence of shape and immobility of the cloud, sixthly for the very long enduraice of the coloured reflected sunlight after suncet, one hour and forty minutes, and seventhly for the second illumination, which began more than an hour after sunset. It was certainly due to cirrus or a higher kind of cloud, because (I.) parts of the illuminated sliy stretched in long streals southwards, and the glow remained lon $g$ in these streaks, resemtling very high cirrus ; (2) when the light left the sky the first time, the part which had been illu. minated remained visible as silvery gray cloud ripples, before the second after-glow rekindled it, and (3) because the colour becau:e very gradually darker as time went $\mathrm{cn}$, and because the recessions of light both times were tow ards the place of sunset. A similar very high cirrus had also been specially marked long aft. sunset on November 8, and about the tiine of sunrise on November 9 . The night following this rare display was exceedingly clear and fine. 'This evening (November 10) the light, high cirrus, all but invisible in full daylight, with its delicate ripiles, assumed the pink tint about fifteen minutes after sunset, showing the upper air to be in the same abnormal condition as yesterd.y, and the phenomenon was feebly repeated. It would be interesting to accertain the approximate height of cirrus on which sunshine remains one hour and forty minutes after sunset at this time of year.

Dunrozel, Haslemere, Surrey, November io

\section{Shadow-Beams in the East at Sunset}

THE phenomenon of bears of shadow meeting in the east at sunset, treated of in the pages of NATURE some months since (at which time you did me the honour of inserting a letter of mine), was beautifully witnessed here to-day and yesterday. Both days were unusually clear; there was, nevertheless, a "body" in the air, without which the propagation of the beams could not talie place. Yesterday the sky was striped with cirrus cloud like the swaths of a hayfield; only in the east there was a bay or reach of clear blue sky, and in this the shadow. beams appeared, slender, colourless, and radiating every way like a fan wide open. This lasted from 3.30 to about 4.30 . To-day the sky was cloudless, except for a low bank in the west; in the east was a "cast" of blue mist, from which sprang alternate broad bands of rose colour and blue, slightly fringed. I was not able to look for them till about $4 \cdot 30$, when the sun was down, and they soon faded. I have not before seen this appearance so far north, but on the south ccast, where I first saw it, I think it might often be witnessed. It is merely an effect of perspective, but a strange and Leautiful one.

Stonyhurst College, Nuvember 12

GERARD Hopkins

\section{The Java Eruption}

THE accompanying paragraph may be of interest in connection with the Java catastrophe. I may mention that from the 28th of last month, when I first noticed it, there has been an exceptional red glow after sundown, and a strange green tint in the sky, while till the last few days the moon has had a distinctly green tint; this green tint has been noticed in many parts of Iidia.

F. C. Constable

Karachi, October 16

A Floating Lava Bed.-Sir,- It may be interesting to some of your scientific readers to know that the steamship Siam, on her voyate from King George's Sound to Colombo, on August I, when in lat. $6^{\circ} \mathrm{S} ., 89^{\circ} \mathrm{E}$, passed, for upwards of four hours, through large quantities of lava, which extended as far as could be seen (the thip was going eleven knots at the time). The lava was fluatirg in a succession of lanes from five to ten yards wide, and trending in a direction north-west to south-east. The nearest land was the coast of Sumatra (distant 7 co miles), but as there was a current of fifteen to thirty miles a day, setting to the tast ward, the lava could not have come from there, and I can only imagine it must have been an upheaval from somewhere near the spot. I may mention the soundings on the chart show over 2,000 fathoms. There was a submarine volcano near the spot in I879.-EDWARD Ashoown, Commander, P. and O. steamship Sian. (Sind Gazette Bulletin, October 12.)

\section{Towering of Birds}

When shootii $g$ in Fifeshire last October I fired at a partridge at a distance of about forty yaris ; the bird flew on for a short distance, and then began to ri e, not in the manner in which a tow ering bird generally ascend, but soaring as if it did so voluntarily. After rising to the height of 100 C.r I 50 yards very much after the fashion in which some hanks soar, its flight was suddenly deflected downwards olliquely for a considerable distance, 